\title{
Morphological and sedimentological assessment of submarine dune fields on the coast of Yucatan, Mexico
}

\section{Evaluación morfológica y sedimentológica de campos de dunas submarinas en la costa de Yucatán, México}

\author{
Eduardo Cuevas ${ }^{1 *}$, María de los Ángeles Liceaga-Correa ${ }^{1}$, Luis A Rincón-Sandoval ${ }^{1}$, Guadalupe \\ Mexicano-Cíntora ${ }^{1}$, Leonardo Arellano-Méndez ${ }^{1}$, Jorge I Euán-Ávila' ${ }^{1}$, Héctor Hernández-Núñez ${ }^{1}$, \\ Sandor Mulsow ${ }^{2}$ \\ ${ }^{1}$ Centro de Investigación y de Estudios Avanzados del Instituto Politécnico Nacional, Unidad Mérida, \\ Km. 6 Antigua Carretera a Progreso, CP 97310, Mérida, Yucatán, México. \\ ${ }^{2}$ Universidad Austral de Chile, Instituto de Ciencias Marinas y Limnológicas, Casilla 567, Valdivia, Chile. \\ * Corresponding author. E-mail: ecuevas@mda.cinvestav.mx
}

\begin{abstract}
Conspicuous sedimentary deposits forming well-structured and prominent submarine dunes are found on the coast of Yucatan (Mexico), close to the ports of Dzilam de Bravo, San Felipe, and El Cuyo. The objective of this study was to evaluate the morphological and sedimentological features of these submarine dunes. Sub-bottom seismologic profiles were obtained and standardized sedimentological analyses were performed on sediment samples collected at the three study sites. Both the height and wavelength of dunes were different between the three sites, mean heights ranging from 0.84 to $2.28 \mathrm{~m}$ and mean wavelengths from 98 to $330 \mathrm{~m}$. Most of the dunes showed a wellmarked asymmetry, which is related to the direction of their movements. Their granulometric composition was dominated by medium, moderately well-sorted sand. This study provides bases for future systematic monitoring of these peculiar ecosystems, including information to be considered for the evaluation of their ecological role in the marine system.
\end{abstract}

Key words: dune field, dune morphology, sub-bottom profiles, sedimentology.

RESUMEN. En la costa del estado de Yucatán existen áreas con campos conspicuos de depósitos sedimentarios que forman dunas submarinas bien estructuradas y sobresalientes, aledaños a los puertos de Dzilam de Bravo, San Felipe y El Cuyo. El objetivo de este trabajo fue evaluar la morfología y las características sedimentológicas de estas dunas sumergidas. Para esto, se obtuvieron perfiles sismológicos del subfondo y se realizaron análisis sedimentológicos estandarizados de muestras recolectadas en los tres sitios de estudio. Tanto la altura de las dunas como su longitud de onda fueron diferentes entre los tres sitios, donde se registraron dunas de entre 0.84 y 2.28 m de altura y con longitudes de onda promedio entre 98 y $330 \mathrm{~m}$. La mayoría de las dunas mostró una asimetría bien marcada, que está relacionada con el sentido en que se mueven. En su composición granulométrica dominó el sedimento superficial del tipo arena media moderadamente bien clasificada. Este trabajo sienta bases para el monitoreo sistemático de estos ecosistemas peculiares, incluyendo información para considerarse en la evaluación del papel ecológico que desempeñan en el sistema.

Palabras clave: campos de dunas, morfología de dunas, perfiles del subfondo, sedimentología.

\section{INTRODUCTION}

Studies on marine sedimentary deposits have been conducted over decades, addressing aspects such as their spatial disposition (Aliotta and Perillo 1987), morphology and internal structure (Todd 2005), grain-size composition and relationship with the environment (Bartholdy et al. 2005), dynamics and behavior (Xu et al. 2008, Gómez et al. 2010), interaction with seagrasses (Daniell et al. 2008), and paleoclimate modeling (Peterson et al. 2010). Active oceanographic equipment (multibeam and side-scan sonar) has been used for their description and assessment. For many years the core extraction method was used to study their internal structure (Murdoch and Azcue 1995), but in the last decade

\section{INTRODUCCIÓN}

Los depósitos sedimentarios marinos sumergidos han sido objeto de estudio por décadas, abordándose temáticas como su disposición espacial (Aliotta y Perillo 1987), morfología y estructura interna (Todd 2005), composición granulométrica y su relación con el medio en que se encuentran (Bartholdy et al. 2005), dinámica y comportamiento de los depósitos sedimentarios (Xu et al. 2008, Gómez et al. 2010), interacción con praderas de pastos marinos (Daniell et al. 2008) y modelaje paleoclimático (Peterson et al. 2010). Su descripción y seguimiento se han realizado con equipos oceanográficos activos (multihaz [multibeam] y sonar de barrido lateral). Por muchos años se recurrió a la extracción de 
the use of seismic reflection techniques has become more widespread (Gómez et al. 2010).

The relevance of these underwater structures is acknowledged worldwide because of the direct and indirect effects they have on the adjacent coastline (Le Bot et al. 2000). In the case of Mexico, as far as we were able to ascertain, the brief description given by Tucker and Wright (1990) of the submarine dunes off Quintana Roo is the only information available. Given the recreational use of the beaches in Yucatan, as well as the ecological, social, and economic importance of the coastal zone for this region, the location and characterization of the submarine dune fields is important because of their association with the sandy shoreline, which currently presents serious problems of erosive degradation in several segments (Cuevas-Jiménez and Euán-Ávila 2009).

The objective of this study was to evaluate the morphological and sedimentological characteristics of three submarine dune fields in the ports of Dzilam de Bravo, San Felipe, and El Cuyo, located in the eastern part of the state of Yucatan, Mexico. This sedimentological and morphological information of the seafloor will be of use in the parameterization of future hydrodynamic and sediment transport models of the region.

\section{MATERIAL AND METHODS}

\section{Study area}

The state of Yucatan is located in the northern part of the Yucatan Peninsula, in southeastern Mexico. The peninsula consists of a wide platform, mainly composed of sedimentary rocks deposited on a Paleozoic basement (Lugo-Hubp et al. 1992), and is one of the youngest structures of the Mexican territory, primarily characterized by karst topography. Among its morphological units is a coastal plain, which is located in the northern part between Cabo Catoche and Celestún (fig. 1) and characterized by a narrow strip of recent marine deposits of biogenic carbonate origin and littoral accumulation. Due to the absence of surface fluvial systems, terrigenous sediments are not found in the area (Lugo-Hubp et al. 1992).

The study area is characterized by low energy waves and east to west longshore sediment transport (Capurro et al. 2002, Cuevas-Jiménez and Euán-Ávila 2009, Enríquez et al. 2010). The rainfall regime marks the seasons. There is a dry season from March to May, a rainy season from June to October, and a Nortes season from November to February (Álvarez-Góngora and Herrera-Silveira 2006), with northerly and northeasterly winds blowing between 5 and $9 \mathrm{~m} \mathrm{~s}^{-1}$ (Enríquez et al. 2010). Tropical storms and hurricanes also occur between August and September (Capurro 2000), with winds blowing from the east and northeast at 2 to $10 \mathrm{~m} \mathrm{~s}^{-1}$. núcleos para el estudio de su estructura interna (Murdoch y Azcue 1995). En la última década ha cobrado mayor auge el uso de técnicas de reflexión sismológica (Gómez et al. 2010).

Alrededor del mundo, se ha enfatizado la relevancia de estas estructuras sumergidas por los efectos directos e indirectos que tienen sobre las líneas de costa adyacentes (Le Bot et al. 2000). Para México, el único estudio encontrado es una breve descripción de dunas submarinas frente a Quintana Roo por Tucker y Wright (1990). Dada la vocación turística de playa del estado de Yucatán, así como la importancia ecológica, social y económica de la zona costera en esta región, la ubicación y caracterización de los campos de dunas submarinas son aspectos trascendentales por su vínculo con la costa arenosa, la cual actualmente presenta serios problemas de degradación erosiva en numerosos segmentos (CuevasJiménez y Euán-Ávila 2009).

El objetivo fue evaluar la morfología y las características sedimentológicas de tres campos de dunas submarinas en los puertos de Dzilam de Bravo, San Felipe y El Cuyo, ubicados al oriente del estado de Yucatán, México. La información sedimentológica y morfológica del fondo marino presentada en este estudio contribuirá a la parametrización de futuros modelos hidrodinámicos y de transporte sedimentológico en la región.

\section{MATERIALES Y MÉTODOS}

\section{Área de estudio}

El estado de Yucatán se ubica en la parte septentrional de la península de Yucatán, al sureste de México. La península es una plataforma amplia conformada mayormente por rocas sedimentarias depositadas sobre un basamento Paleozoico (Lugo-Hubp et al. 1992). Ésta es una de las estructuras más jóvenes del territorio mexicano y se distingue principalmente por un desarrollo cárstico. Entre sus unidades morfológicas se encuentra una planicie costera, ubicada en la porción norte desde cabo Catoche hasta Celestún (fig. 1), que se caracteriza por una franja estrecha de depósitos marinos recientes de origen carbonatado biogénico y un litoral de acumulación. Debido a la ausencia de un sistema fluvial superficial, en esta zona no se presentan sedimentos de origen terrígeno (LugoHubp et al. 1992).

El área de estudio presenta oleaje de baja energía y un transporte litoral de sedimentos principalmente de este a oeste (Capurro et al. 2002, Cuevas-Jiménez y Euán-Ávila 2009, Enríquez et al. 2010). El régimen de lluvias marca el patrón climático. La temporada de secas es de marzo a mayo, la de lluvias es de junio a octubre y la de nortes es de noviembre a febrero (Álvarez-Góngora y Herrera-Silveira 2006), con vientos del norte y noreste a velocidades de entre 5 y $9 \mathrm{~m} \mathrm{~s}^{-1}$ (Enríquez et al. 2010). También existe una temporada de tormentas y huracanes que ocurre de agosto a septiembre (Capurro 2000), y los vientos en este tiempo provienen del este y noroeste a velocidades de entre 2 y $10 \mathrm{~m} \mathrm{~s}^{-1}$. 

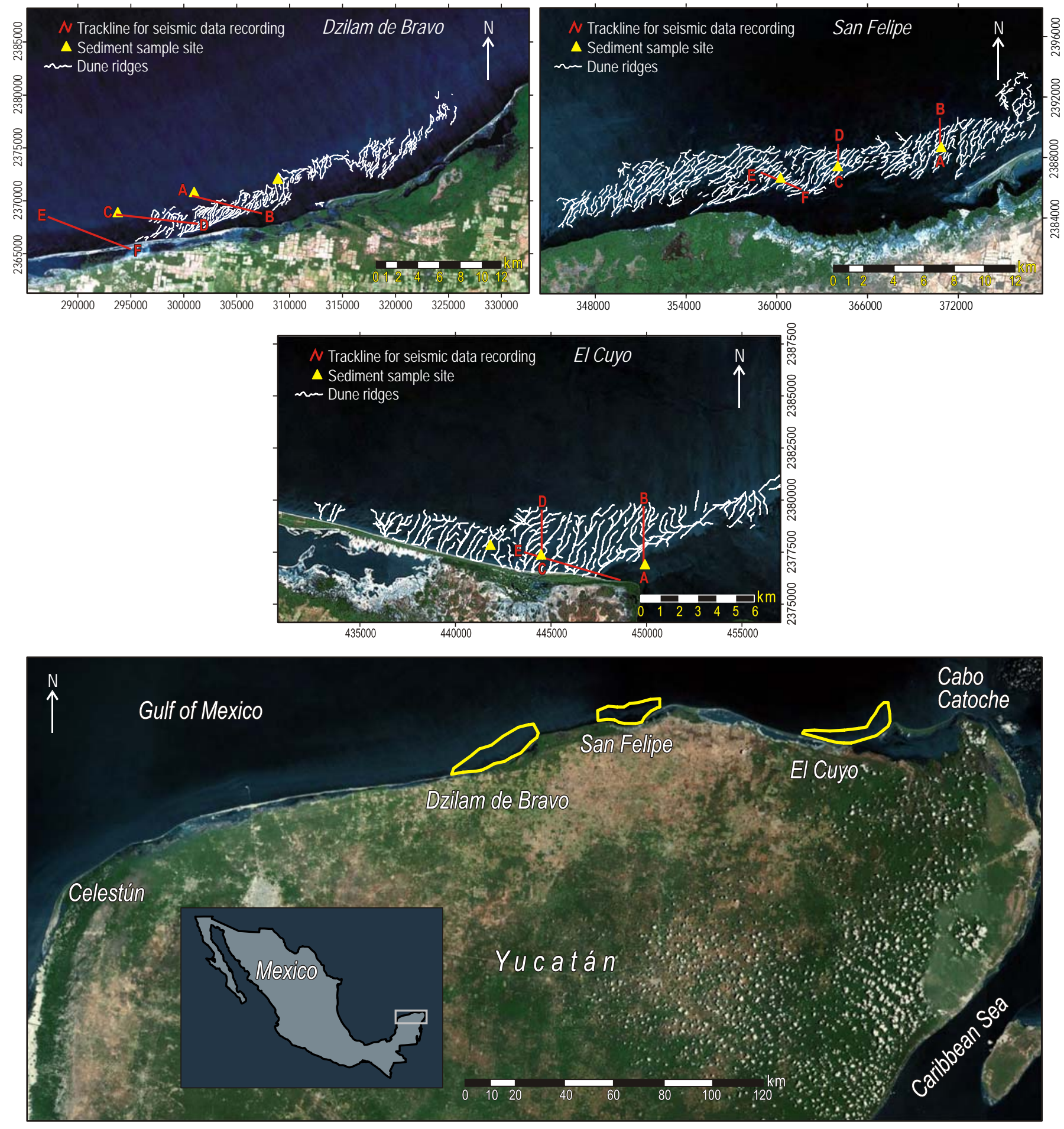

Figure 1. Location of the study sites (inside yellow polygons) on the coast of Yucatan, southeastern Mexico. The insets present the insonified tracklines (red lines) for seismic data recording of the dune fields at Dzilam de Bravo, San Felipe, and El Cuyo. The most prominent dune ridges (white lines) and sediment sampling sites (yellow triangles) in the areas are schematized.

Figura 1. Localización de los sitios de estudio (dentro de polígonos amarillos) en la costa de Yucatán, sureste de México. Las inserciones presentan los transectos barridos (líneas rojas) para el registro de los datos sísmicos de los campos de dunas en Dzilam de Bravo, San Felipe y El Cuyo; se esquematizan las crestas de dunas más prominentes (líneas blancas) y los sitios de muestreo de sedimentos (triángulos amarillos). 


\section{Dune morphology}

Despite the numerous studies carried out worldwide on this subject, establishing a standardized nomenclature for the different sedimentary deposits has proved controversial, though the compilations made by Ashley (1990) and Perillo (2001) have enabled greater standardization. According to these authors, the consensus of experts is that the term "dune" be used to refer to transverse sedimentary deposits.

The following morphological elements are used to define dunes: crest (highest elevation of the dune), ramp side (shallow upslope), leeward side (steep downslope), trough (point where a perceptible change in slope indicates the beginning or end of the dune), and wavelength (distance between successive crests) (Allen 1980, Perillo 2001). Asymmetry is also an important characteristic for the morphological evaluation of submerged dunes as it is a reliable indicator of the direction of their movement and an indirect indicator of net sediment transport direction (Perillo 2001).

For the morphological evaluation presented here, seismic data were collected in October and November 2010, using a Syqwest StrataBox Chirp sub-bottom profiler $(10 \mathrm{kHz})$ mounted aboard a boat with outboard motor. Transects of variable length, perpendicular and longitudinal to the coastline, were sampled over the dune fields at depths between 2 and $5 \mathrm{~m}$. Data were analyzed using Kingdom Suite 8.5 software (Seismic Micro-Technology, Inc. 2009), applying a passband filter of 1 to $7 \mathrm{kHz}$ to each data set.

Dune wavelength $(\lambda)$ and height $(h)$ were measured using the seismic images. Based on the values of these morphological features and when the data met the assumptions of normality and homoscedasticity $(P>0.05)$, analysis of variance was used to assess the morphological differences between the three study sites.

According to Flemming (2000), the depth of the site where the dunes are located and the sediment grain size of the dunes are first-order descriptors of their latest stage of development; hence, the equation proposed by this author, $H_{\max }=0.16 \lambda^{0.84}$, was used to estimate a maximum theoretical reference height for comparison with the true measured heights, taking as limits $9.0 \mathrm{~m}$ (for dunes formed by sediments with a D50 value $=126-250 \mu \mathrm{m}$ ) and $24 \mathrm{~m}$ (for dunes formed by sediments with a D50 value $=251-500 \mu \mathrm{m}$ ).

Considering that the direction of dune movement is correlated with the asymmetry and sediment transport dynamics over the dunes (Perillo 2001, Xu et al. 2008), a simple asymmetry index was derived. Asymmetry was quantified using the following relation: $h /\left(\lambda_{1}-\lambda_{2}\right)$, where $\lambda_{1}$ and $\lambda_{2}$ correspond to the distance from the crest to the trough at the left and right sides, respectively, of any dune, taking as reference the point of the crest projected over the base of any dune recorded in the seismic profile. Index values close to zero indicate high asymmetry, whereas higher values (negative or positive) indicate strong symmetry. The sign of the value refers to the direction of dune movement, a negative

\section{Morfología de las dunas}

A pesar de la amplia gama de estudios realizados alrededor del mundo sobre este tema, existe controversia sobre el establecimiento de una nomenclatura estandarizada que se aplique para nombrar a los diferentes depósitos sedimentarios. Entre los mayores avances hacia una estandarización se encuentran las compilaciones hechas por Ashley (1990) y Perillo (2001), quienes expresan el consenso de especialistas por adoptar la palabra "duna" como término único estandarizado para referirse a las formas de depósitos sedimentarios transversales.

Para las dunas, se han definido los siguientes elementos morfológicos: cresta (punto más elevado de la duna), rampa (flanco de la duna ubicado corriente arriba de la cresta, pendiente de menor inclinación), talud (flanco de la duna ubicado corriente abajo de la cresta, pendiente pronunciada), línea de seno (punto donde se puede inferir un cambio en la pendiente que suele indicar el inicio o fin de la duna) y longitud de onda (distancia entre senos de la duna) (Allen 1980, Perillo 2001). Una característica relevante para la evaluación morfológica de las dunas submarinas es la asimetría, que es un indicador confiable de su sentido de traslación e indicador indirecto de la dirección de transporte neto sedimentario (Perillo 2001).

Para la evaluación morfológica en el presente estudio, se recolectaron datos sismológicos en octubre y noviembre de 2010 con un perfilador sismológico de fuente acústica tipo Chirp, modelo Strata Box (Syqwest, Inc.), $10 \mathrm{kHz}$, montado en una embarcación con motor fuera de borda. Se recorrieron transectos de longitud variable sobre las áreas de dunas, de forma perpendicular y longitudinal a la costa, a profundidades de entre 2 y $5 \mathrm{~m}$. Los datos fueron analizados con el software Kingdom Suite 8.5 (Seismic Micro-Technology, Inc. 2009), aplicando un filtro pasabanda de 1 a $7 \mathrm{kHz}$ a cada línea de datos.

Se midió la longitud de onda de las dunas $(\lambda)$ y su altura (h) utilizando las imágenes sismológicas. A partir de los valores de estas características morfológicas y toda vez que los supuestos de normalidad y homoscedasticidad de los datos fueron cumplidos $(P>0.05)$, se realizaron pruebas de análisis de varianza para evaluar diferencias morfológicas entre las tres localidades de estudio.

Flemming (2000) reconoce que la profundidad del sitio en que se encuentran las dunas y el tamaño del grano de sedimento que las conforman son factores de primer orden que delimitan su desarrollo final. Con base en esto, se utilizó la ecuación $H_{\max }=0.16 \lambda^{0.84}$ propuesta por Flemming (2000) para la estimación de una altura teórica máxima de referencia y comparación con las alturas reales medidas, teniendo como límites $9 \mathrm{~m}$ (para dunas formadas por sedimento con valor $\mathrm{D} 50=126-250 \mu \mathrm{m}$ ) y $24 \mathrm{~m}$ (para dunas formadas por sedimento con valor D50 $=251-500 \mu \mathrm{m}$ ).

Considerando que el sentido de traslación de la duna está correlacionado con la asimetría y la dinámica de transporte 
sign indicating onshore movement and a positive sign, offshore movement.

We chose to use this reference system because if the wavelength components $\left(\lambda_{x}\right)$ are fixed to a specific side (ramp or leeward; i.e., $\lambda_{1}$ always the ramp side component), the sign of the quotient obtained would not vary and thus complicate the interpretation of the direction of movement in each profile.

Finally, the dunes were classified based on their morphological types (erosional or depositional) based on the criteria exposed and used by Palomino et al. (2009).

\section{Sediment analysis}

At each of the study sites (Dzilam de Bravo, San Felipe, and El Cuyo), sediment samples were taken from three dune crests (nine samples in total) (fig. 1) using a PVC pipe $(60 \mathrm{~cm}$ long and $5 \mathrm{~cm}$ inner diameter). As marked stratification in the sediment cores was not visually observed, they were divided transversely to obtain two subsamples of approximately $8 \mathrm{~cm}$ length (amount of sediment required to complete the weight necessary for the granulometric analysis), thus differentiating the surface and sub-bottom sediments.

Particle size analysis was conducted according to the method described by Folk (1980), using samples of $50 \mathrm{~g}$ $( \pm 0.001)$ and a stack of seven sieves $(\varphi:-1,0,1,2,3,4$, and 5), with a sieving time of $15 \mathrm{~min}$.

The following statistical parameters were estimated: mean grain size, standard deviation, skewness, and kurtosis. Bivariate dispersion plots were elaborated with these parameters and the discriminant functions $\left(Y_{2}\right.$ and $\left.Y_{3}\right)$ proposed by Sahu (1964) were applied to characterize the deposition scenario for the study sites.

\section{RESULTS}

\section{Dune morphology}

Dunes of variable extension were observed at both Dzilam de Bravo (DBR) and San Felipe (SFE) (fig. 1), and those closest to shore were higher. At El Cuyo (ELC) (fig. 1) we observed a sediment deposit forming a group of interconnected dunes, their thickness decreasing northwards with increasing depth.

Dune heights $(h)$ and their respective wavelengths $(\lambda)$ (table 1) were lowest at DBR, intermediate at SFE, and highest at ELC (fig. 2). DBR was the only site at which there were no significant statistical differences in wavelength between transects (DBR: Fisher's $F=2.75$, degrees of freedom (d.f.) $=2, P=0.0743$; SFE: $F=9.36$, d.f. $=2$, $P=0.0018$; ELC: $F=3.50$, d.f. $=2, P=0.0472)$. Significant statistical differences in mean dune height between transects were not observed at DBR and SFE (DBR: $F=0.76$, d.f. $=2$, $P=0.4726$; SFE: $F=1.19$, d.f. $=2, P=0.3290)$, but they were found at $\operatorname{ELC}(F=7.43$, d.f. $=2, P=0.0032)$ (table 1 , fig. 1). de sedimento sobre las dunas (Perillo 2001, Xu et al. 2008), se derivó un índice simple de asimetría. La asimetría se cuantificó mediante la relación $h /\left(\lambda_{1}-\lambda_{2}\right)$, donde $\lambda_{1}$ y $\lambda_{2}$ corresponden a la distancia de la cresta a la línea de seno de los lados izquierdo y derecho, respectivamente, de cualquier duna, considerando como referencia central el punto de su cresta proyectado sobre la base de cualquier duna registrada en un perfil sismológico. Valores de este índice cercanos a cero indican una alta asimetría, mientras que valores mayores (negativos o positivos) indican una fuerte simetría. El signo del valor refiere el sentido del movimiento de la duna; el signo negativo indica movimiento hacia la costa y el positivo, hacia mar adentro.

Se optó por el uso de este sistema de referencia porque si se fijara cualquiera de los componentes de la longitud de onda $\left(\lambda_{x}\right)$ a un flanco específico (rampa o talud; i.e., $\lambda_{1}$ siempre como el componente de la rampa), el signo del cociente obtenido no variaría, haciendo complicada la interpretación del rumbo de desplazamiento en cada perfil.

Finalmente, se clasificaron las dunas por sus tipos morfológicos (erosivo o deposicional) utilizando como base los criterios expuestos y utilizados por Palomino et al. (2009).

\section{Análisis sedimentológico}

En cada una de las tres localidades estudiadas (Dzilam de Bravo, San Felipe, and El Cuyo) se definieron tres sitios para la toma de muestras de sedimento en las crestas de igual número de dunas (nueve sitios en total) (fig. 1). Para la recolecta, se utilizó un nucleador de PVC de $60 \mathrm{~cm}$ de longitud y $5 \mathrm{~cm}$ de diámetro. Debido a que a simple vista no se observó una estratificación marcada en los núcleos, éstos se dividieron transversalmente para obtener dos submuestras de aproximadamente $8 \mathrm{~cm}$ de longitud (cantidad de sedimento requerido para completar el gramaje necesario en el análisis granulométrico), diferenciando de esta forma el sedimento superficial y el de subfondo.

Para el análisis granulométrico se siguió la técnica estandarizada de Folk (1980); se utilizaron muestras de $50 \mathrm{~g}$ $( \pm 0.001)$ y un tren de siete tamices $(\varphi:-1,0,1,2,3,4$ y 5$)$ y un tiempo de tamizado de $15 \mathrm{~min}$.

A partir de los datos de procesamiento de las submuestras, se estimaron los siguientes parámetros estadísticos gráficos: tamaño promedio de grano, desviación estándar, grado de asimetría y medida de curtosis. Con estos parámetros se elaboraron gráficas bivariantes de dispersión, y se aplicaron las funciones discriminantes $\left(Y_{2}\right.$ y $\left.Y_{3}\right)$ propuestas por Sahu (1964) para caracterizar el escenario de depósito de las localidades estudiadas.

\section{RESULTADOS}

\section{Morfología de dunas}

Tanto en Dzilam de Bravo (DBR) como en San Felipe (SFE) (fig. 1), se observaron dunas de extensión variable, y 
Ciencias Marinas, Vol. 39, No. 1, 2013

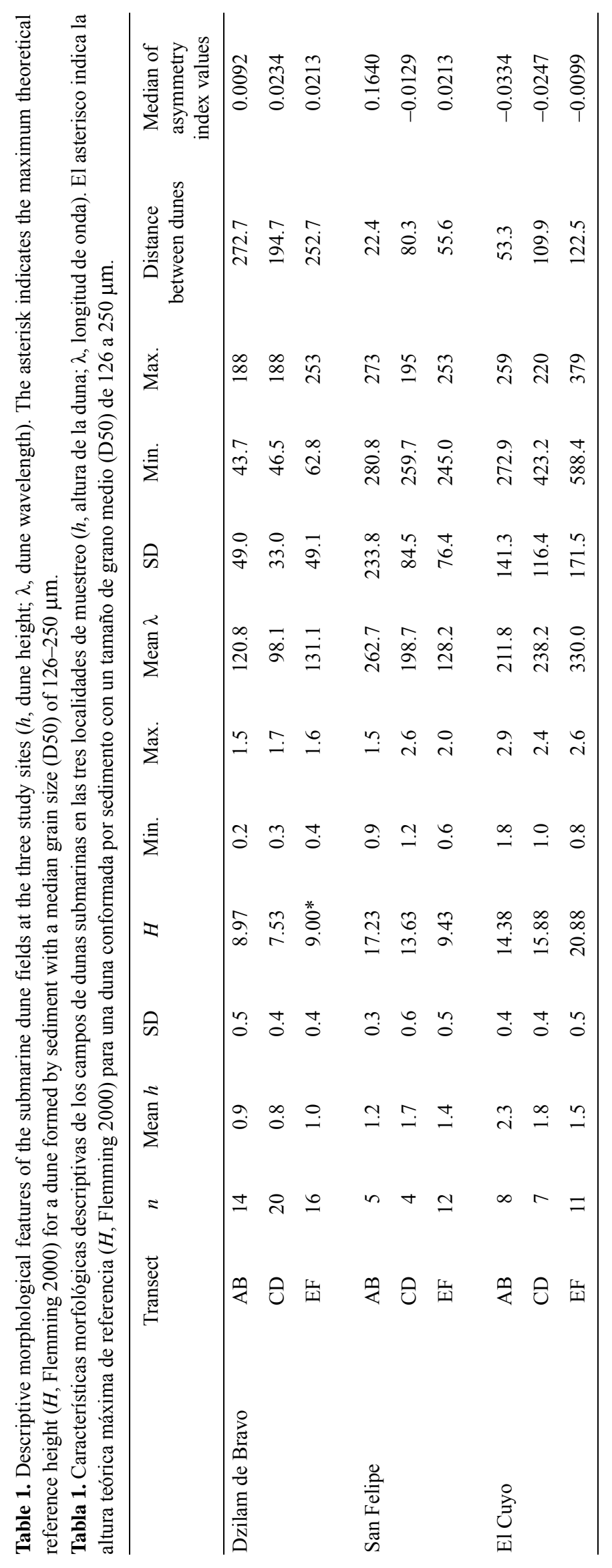




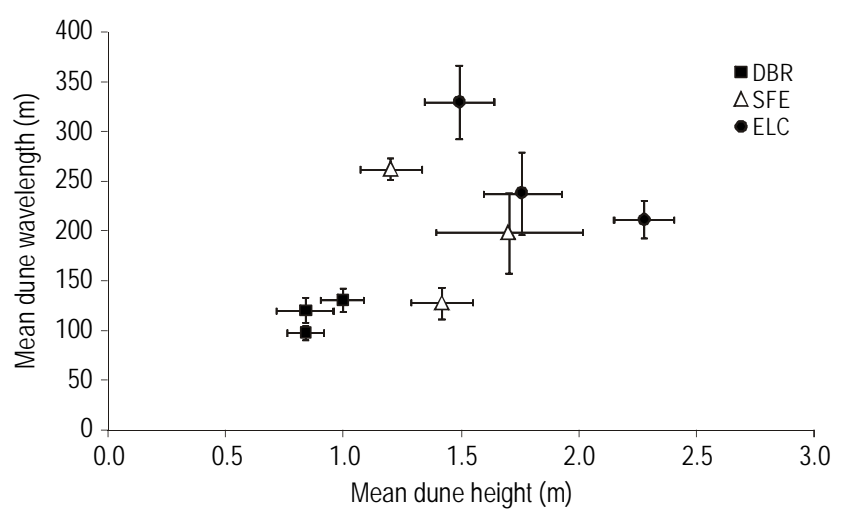

Figure 2. Dune height and wavelength ratios for the dune fields at Dzilam de Bravo (DBR), San Felipe (SFE), and El Cuyo (ELC), Yucatan. Individual typical mean error is represented by vertical and horizontal bars for each set of dunes registered at the nine seismic transects.

Figura 2. Altura y longitud de onda de las dunas en Dzilam de Bravo (DBR), San Felipe (SFE) y El Cuyo (ELC), Yucatán. El error típico de la media se representa mediante barras verticales y horizontales para cada grupo de dunas registrado en los nueve transectos sísmicos.

The theoretical reference values of potential maximum heights for these sites ranged from $8 \mathrm{~m}$ at DBR (D50 = $126-250 \mu \mathrm{m})$ to 17 and $20 \mathrm{~m}$ at SFE and ELC (D50 = $251-500 \mu \mathrm{m})$, respectively.

Most of the dunes identified at DBR were asymmetric and trending predominantly northwestward (fig. 3). Greater variability in dune movement was observed at SFE, where south- and northwest-trending dunes were recorded; in this area we observed apparently eroded dunes and some merged dunes with converging asymmetries (fig. 4). A predominant direction of dune movement was not observed at ELC, where north- and south-trending dunes were recorded, though in some parts all dunes moved in a single direction (fig. 5).

More than $50 \%(n=52)$ of the total of dunes analyzed at all three sites together $(N=96)$ moved towards deeper areas and the rest in the opposite direction (fig. 6). At DBR, $66 \%(n=33)$ of the total of dunes $(N=50)$ moved towards deeper areas and $34 \%(n=17)$ moved in the opposite direction $\left(-0.54 \leq h /\left(\lambda_{1}-\lambda_{2}\right) \leq 0.13\right)$. At SFE, $70 \%(n=14)$ of the total of dunes $(N=20)$ moved towards deeper areas and $30 \%$ $(n=6)$ in the opposite direction $\left(-0.12 \leq h /\left(\lambda_{1}-\lambda_{2}\right) \leq 0.68\right)$. At ELC, $19 \%(n=5)$ of the total of dunes $(N=26)$ moved towards deeper areas and $81 \%(n=21)$ in the opposite direction $\left(-0.11 \leq h /\left(\lambda_{1}-\lambda_{2}\right) \leq 0.22\right)$ (fig. 6$)$.

We observed an uncertain behavior regarding the direction of dune movement and the distance from the coast, especially at DBR and SFE, where there was a shift in the direction of skew as the distance from the coast increased (fig. 6).

All dunes were classified as depositional morphologicaltype, and asymetric dunes dominated. aquellas más cercanas a la costa fueron las de mayor altura. En El Cuyo (ELC) (fig. 1) se registró un depósito sedimentario que conforma un conjunto de dunas interconectadas entre sí, y su espesor disminuyó hacia el norte con el incremento de la profundidad.

Dadas las condiciones de altura de las dunas $(h)$ y su respectiva longitud de onda $(\lambda)$ (tabla 1), en DBR se localizaron las dunas más bajas y angostas; en SFE, las dunas de altura y longitudes de onda intermedias; y en ELC, las dunas más altas y anchas (fig. 2). Dzilam de Bravo fue la única localidad en que no se encontraron diferencias estadísticamente significativas en la longitud de onda de las dunas entre transectos (DBR: $F$ de Fisher $=2.75$, grados de libertad (g.l.) $=2, P=$ 0.0743; SFE: $F=9.36$, g.l. $=2, P=0.0018$; ELC: $F=3.50$, g.l. $=2, P=0.0472$ ). Por otro lado, no se detectaron diferencias estadísticamente significativas en la altura promedio de las dunas entre los transectos de DBR y SFE (DBR: $F=0.76$, g.l. $=2, P=0.4726$; SFE: $F=1.19$, g.l. $=2, P=0.3290$ ). Sin embargo, en ELC sí se encontraron diferencias estadísticamente significativas entre los transectos $(F=7.43$, g.l. $=2$, $P=0.0032)$ (tabla 1, fig. 1).

Los valores teóricos referenciales de alturas máximas potenciales para estas localidades variaron de $8 \mathrm{~m}$ en DBR $(\mathrm{D} 50=126-250 \mu \mathrm{m})$ a 17 y $20 \mathrm{~m}$ en SFE y ELC $(\mathrm{D} 50=$ 251-500 $\mu \mathrm{m})$, respectivamente.

La mayoría de las dunas identificadas en DBR fueron asimétricas, con un sentido de movimiento predominantemente hacia el noroeste (fig. 3). En SFE, se encontró una mayor variabilidad en el sentido de movimiento de las dunas, con traslaciones hacia el sur y noroeste. En esta zona se registraron dunas aparentemente erosionadas y otras fusionadas con asimetrías convergentes (fig. 4). En ELC no se registró una clara dominancia del rumbo de movimiento de las dunas, definiéndose dunas con movimiento en sentido norte y sur, aunque en algunas zonas sí se observó un solo sentido de movimiento de todas las dunas (fig. 5).

Más del 50\% $(n=52)$ del total de dunas analizadas en las tres localidades en conjunto $(N=96)$ se desplazó hacia zonas más profundas y el resto en sentido contrario (fig. 6). En DBR el 66\% $(n=33)$ del total de dunas $(N=50)$ se desplazó hacia zonas de aguas más profundas, y el $34 \%(n=17)$ en sentido contrario $\left(-0.54 \leq h /\left(\lambda_{1}-\lambda_{2}\right) \leq 0.13\right)$. En SFE el $70 \%$ $(n=14)$ del total de dunas $(N=20)$ se movió hacia aguas más profundas y el $30 \%(n=6)$ en sentido contrario $(-0.12 \leq$ $\left.h /\left(\lambda_{1}-\lambda_{2}\right) \leq 0.68\right)$. En ELC el $19 \%(n=5)$ del total de dunas $(N=26)$ se movió hacia aguas más profundas y el $81 \%(n=$ 21) en sentido contrario $\left(-0.11 \leq h /\left(\lambda_{1}-\lambda_{2}\right) \leq 0.22\right)$ (fig. 6).

Se registró un comportamiento incierto respecto a la dirección del movimiento de las dunas y la distancia a la costa, particularmente en DBR y SFE, donde se observó un cambio del sentido de asimetría conforme se alejaban de la línea de costa (fig. 6).

Todas las dunas fueron clasificadas como depósitos del tipo morfológico deposicionales, predominantemente de tipo asimétricas. 

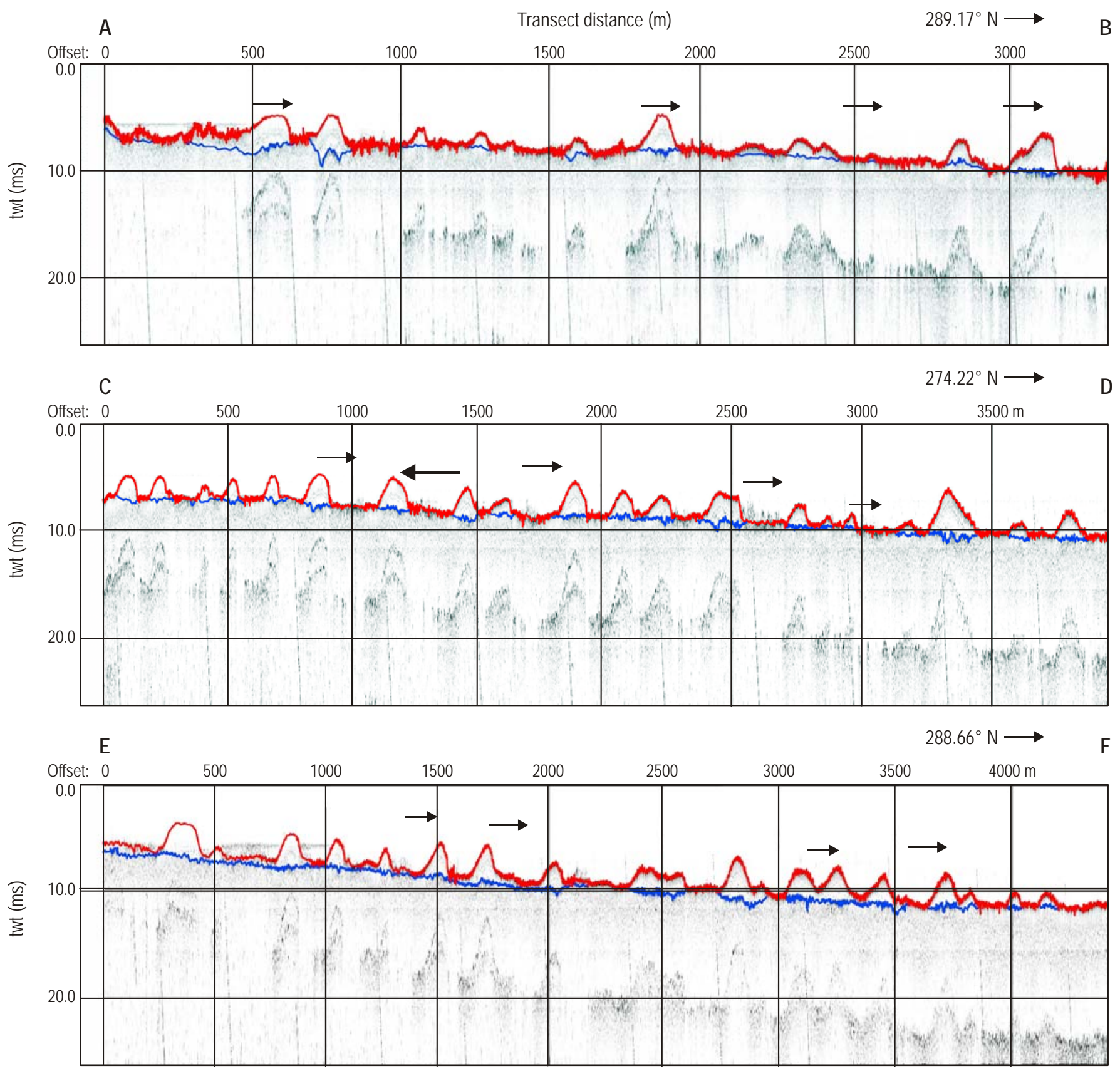

Figure 3. Seismic profile images recorded at three insonified transects $(A B, C D, E F)$ in Dzilam de Bravo. The images show the sea bottom horizon (red line) and sub-bottom horizon (blue line). Black arrows indicate the direction of dune movement as assumed according to their asymmetry. The orientation of each transect relative to magnetic north is indicated.

Figura 3. Imágenes del perfil sísmico registradas en tres transectos insonificados (AB, CD, EF) en Dzilam de Bravo. Las imágenes muestran el horizonte del fondo (línea roja) y el horizonte del subfondo (línea azul). Las flechas negras indican el sentido de traslación de las dunas según su asimetría. Se indica la orientación de cada transecto con respecto al norte magnético. 

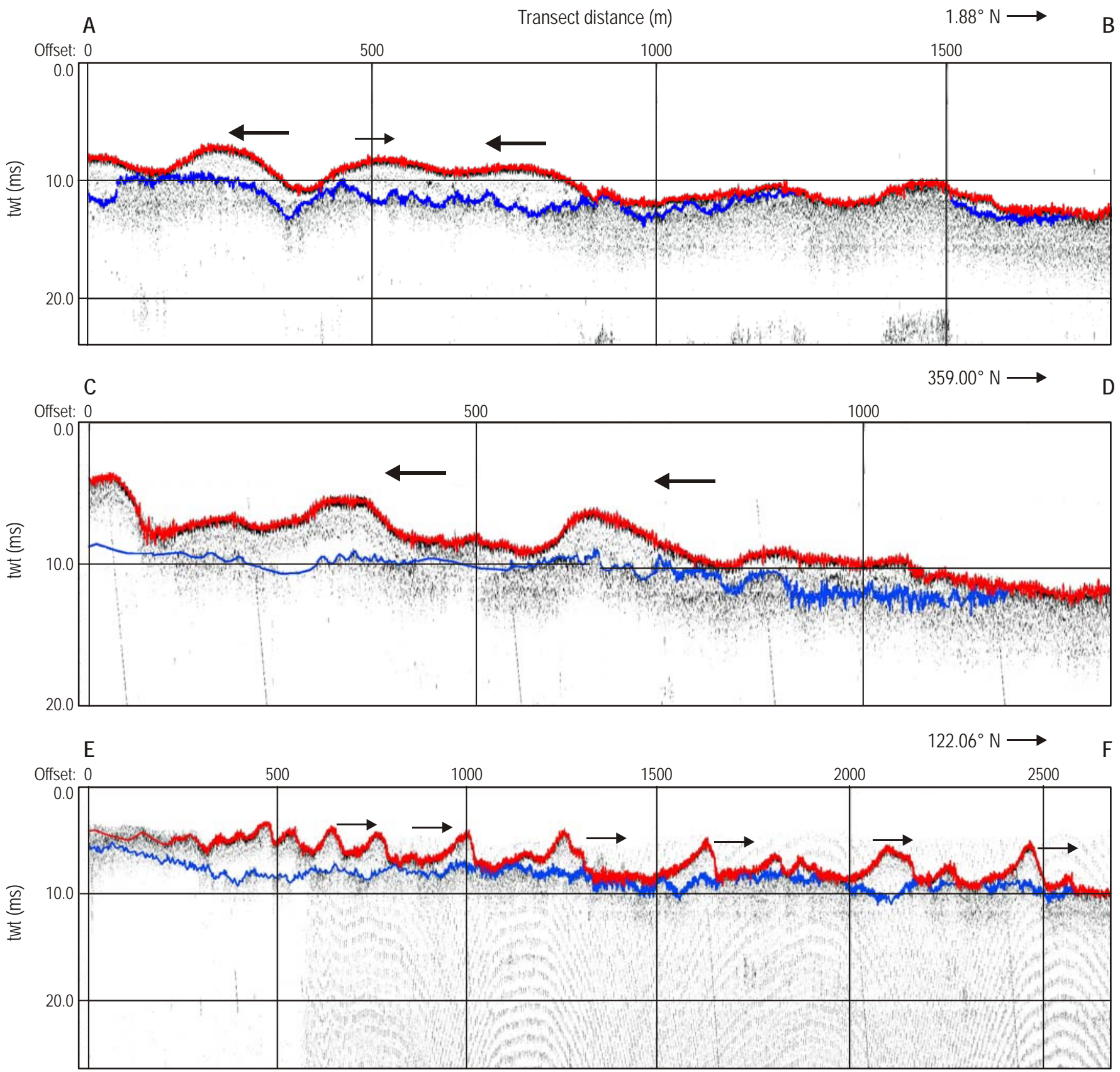

Figure 4. Seismic profile images recorded at three insonified transects (AB, CD, EF) in San Felipe. The images show the sea bottom horizon (red line) and sub-bottom horizon (blue line). Black arrows indicate the direction of dune movement as assumed according to their asymmetry. The orientation of each transect relative to magnetic north is indicated.

Figura 4. Imágenes del perfil sísmico registradas en tres transectos insonificados $(A B, C D, E F)$ en San Felipe. Las imágenes muestran el horizonte del fondo (línea roja) y el horizonte del subfondo (línea azul). Las flechas negras indican el sentido de traslación de las dunas según su asimetría. Se indica la orientación de cada transecto con respecto al norte magnético. 

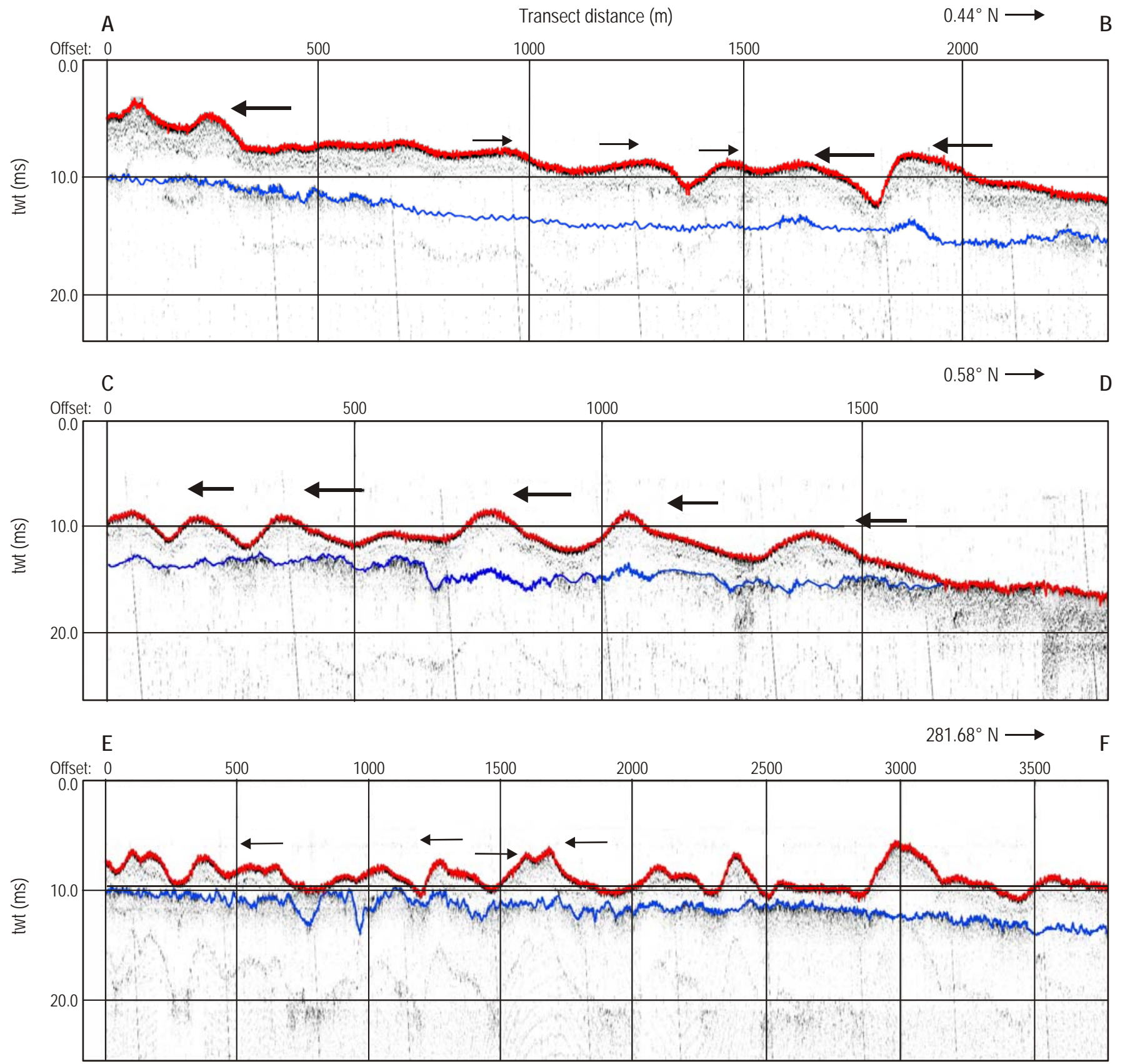

Figure 5. Seismic profile images recorded at three insonified transects (AB, CD, EF) in El Cuyo. The images show the sea bottom horizon (red line) and sub-bottom horizon (blue line). Black arrows indicate the direction of dune movement as assumed according to their asymmetry. The orientation of each transect relative to magnetic north is indicated.

Figura 5. Imágenes del perfil sísmico registradas en tres transectos insonificados $(\mathrm{AB}, \mathrm{CD}, \mathrm{EF})$ en El Cuyo. Las imágenes muestran el horizonte del fondo (línea roja) y el horizonte del subfondo (línea azul). Las flechas negras indican el sentido de traslación de las dunas según su asimetría. Se indica la orientación de cada transecto con respecto al norte magnético. 


\section{Sediment analysis}

The sediments collected at all three sites consisted mainly of medium and fine sands. There was a slight increase in the proportion of coarse material in the sub-bottom samples, especially at the western sites of each sampling area (fig. 7).

Sediments were classified as moderately sorted, tending to moderately well sorted as the grain size decreased (fig. 8a). Skewness was mainly negative (excess of coarse components) (fig. 8b), with mesokurtic distribution (fig. 8c). Based on the median grain size (D50), the SFE and ELC sediment was classified as medium sand and the DBR sediment as fine sand.

The sediment samples collected did not show a clear stratification. Nonetheless, the mean $\varphi$ values indicated the presence of slightly finer material at the surface than the subbottom in DBR and ELC, whereas similar values were obtained for both levels at SFE. The standard deviation indicated moderately sorted sands in the surface and sub-bottom layers of DBR and SFE, and poorly sorted sands at SFE, especially in the sub-bottom layer (table 2).

At DBR, the distribution of the sediment tended to shift from negatively asymmetric at the surface to symmetric at the sub-bottom, whereas an inverse trend was observed at ELC and negative skewness was recorded for both levels at SFE. At DBR and SFE, mesokurtic sediments dominated in both the surface and sub-bottom layers, whereas at ELC there was greater leptokurtic distribution at the surface and platykurtic distribution at the sub-bottom.

Finally, the discriminant functions showed that most of the samples $(N=15)$ corresponded to a shallow agitated marine environment $\left(Y_{2}>65.365, Y_{3}>-7.419\right)$ and only three sub-bottom samples, one from each site, to a fluvial agitated environment (DBR: $Y_{2}=125, Y_{3}=-9.7$; SFE: $Y_{2}=95$, $Y_{3}=-8.1$; and ELC: $\left.Y_{2}=152, Y_{3}=-15.2\right)$.

\section{DISCUSSION}

\section{Dune morphology}

The ELC dunes in general showed the greatest heights and wavelengths even when some values overlapped with those recorded for SFE. The dunes at DBR, however, were completely different.

At the ELC dune field we observed ample availability of unconsolidated sediment, wide dunes and sedimentary layers of variable height between them, as well as a lack of subaquatic vegetation whose settlement and consolidation is likely determined by the specific hydrodynamic conditions of the area (Daniell et al. 2008). In environments like ELC, the conditions of seafloor roughness indicate a particular hydrodynamics that makes them hostile for plant communities such as marine phanerogams. These high-energy environments do not allow plant seeds to settle (Ryan et al. 2007, Daniell et al. 2008), thus explaining the absence of vegetation.

\section{Análisis sedimentológico}

Los sedimentos recolectados en las tres localidades presentaron arena media y fina principalmente. Se observó un ligero incremento en la proporción de material grueso en las muestras del subfondo, especialmente en sitios al oeste de cada localidad (fig. 7).

Se definió una clasificación moderada para los sedimentos, con tendencia hacia una moderadamente bien clasificada a medida que el tamaño de grano disminuyó (fig. 8a). La asimetría fue principalmente negativa (exceso de componentes gruesos) (fig. 8b), con distribución mesocúrtica (fig. 8c). Con base en sus valores del diámetro medio (D50), el sedimento de SFE y ELC se clasificó como arena media, y el de DBR como fina.

No se registró una estratificación clara en las muestras recolectadas. No obstante, el valor medio de $\varphi$ de los sedimentos indicó la presencia de material ligeramente más fino a nivel de superficie que en el subfondo en DBR y ELC, mientras que el valor fue similar en ambos niveles en SFE. La desviación estándar indicó sedimentos con clasificación moderada en la superficie y el subfondo para DBR y SFE, y pobre clasificación en ELC, principalmente en el subfondo (tabla 2).

En DBR la distribución de los datos del sedimento tendió a cambiar de asimétrica negativa en superficie a simétrica en el subfondo, mientras que en ELC la tendencia fue inversa y en SFE la distribución presentó asimetría negativa en ambos niveles. En DBR y SFE dominó el sedimento con características mesocúrticas en la superficie y el subfondo; en contraste, para ELC se registró una mayor distribución leptocúrtica en la superficie y platicúrtica en el subfondo.

Finalmente, según las funciones discriminantes, la mayoría de las muestras $(N=15)$ se clasificaron en un escenario marino somero agitado $\left(Y_{2}>65.365, Y_{3}>-7.419\right)$, y sólo tres muestras del subfondo se ubicaron en un ambiente fluvial agitado, una en cada localidad (DBR: $Y_{2}=125, Y_{3}=-9.7$; SFE: $Y_{2}=95, Y_{3}=-8.1$; $y$ ELC: $\left.Y_{2}=152, Y_{3}=-15.2\right)$.

\section{Discusión}

\section{Morfología de dunas}

Las dunas en ELC presentaron, en general, las mayores alturas y longitudes de onda, aun cuando los valores se traslaparon en alguna proporción con los observados para SFE. Las dunas en DBR fueron completamente diferentes.

Se observó que el campo de dunas en ELC es un sitio con gran disponibilidad de sedimento no consolidado, dunas anchas y capas sedimentarias de altura variable entre ellas, y sin vegetación subacuática; se sugiere que este campo de dunas es fijado y consolidado por las condiciones hidrodinámicas específicas en el área (Daniell et al. 2008). En ambientes como ELC, las condiciones particulares de rugosidad del fondo hacen suponer una hidrodinámica particular que 

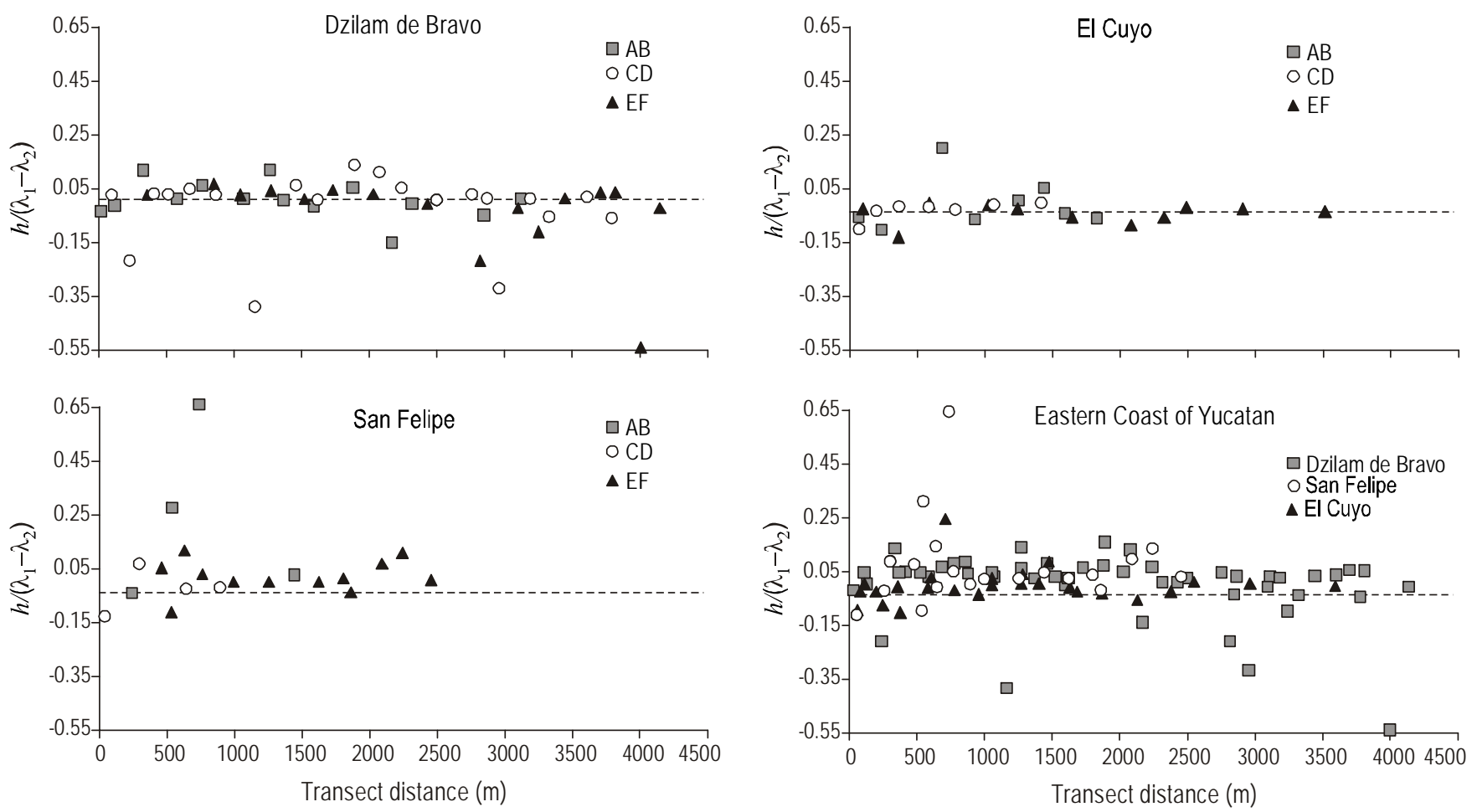

Figure 6. Asymmetry index for the dunes recorded along the transects (AB, CD, EF) studied at Dzilam de Bravo, San Felipe, and El Cuyo, as well as the three locations together.

Figura 6. Índice de asimetría de las dunas registradas en los transectos (AB, CD, EF) realizados en Dzilam de Bravo, San Felipe y El Cuyo, así como los tres sitios en conjunto.

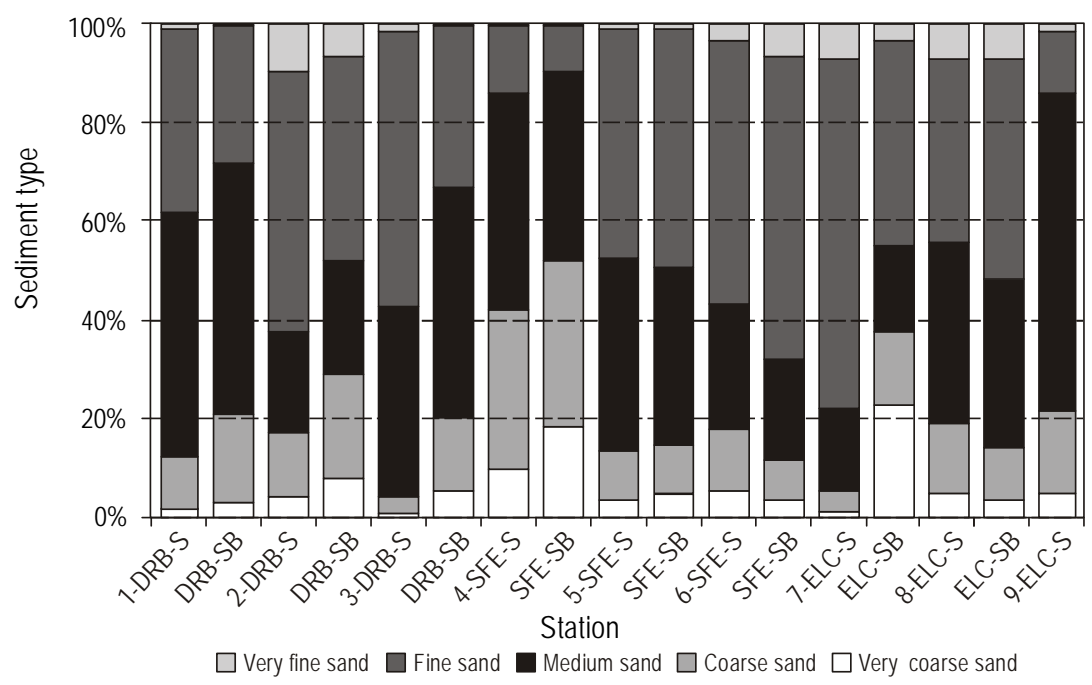

Figure 7. Surface (S) and sub-bottom (SB) sediment grain size distribution at Dzilam de Bravo (DBR), San Felipe (SFE), and El Cuyo (ELC), Yucatan.

Figura 7. Distribución del tamaño de grano superficial (S) y el subfondo (SB) en Dzilam de Bravo (DBR), San Felipe (SFE) y El Cuyo (ELC), Yucatán. 

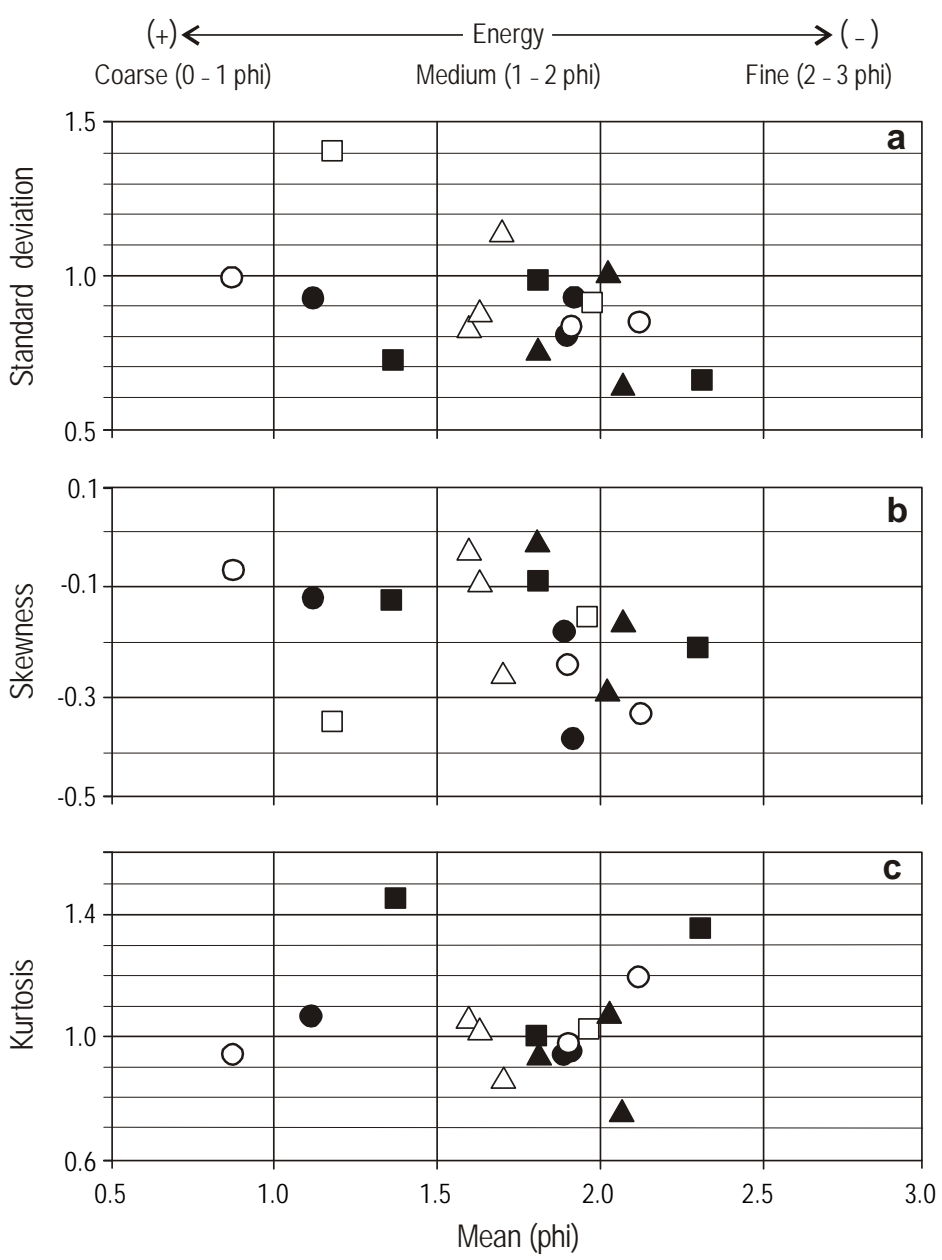

\section{Sorting}

Poorly (1.0-2.0)

Moderately $(0.7-1.0)$

Moderadately well $(0.5-0.7)$

\section{Skewness}

Symmetrical (0.1-0.1)

Coarse $(-0.1-0.3)$

Very coarse $(-0.3-1.0)$

\section{Kurtosis}

Leptokurtic (1.11-1.50)

Mesokurtic (0.90-1.11)

Platykurtic (0.67-0.90)

DBR-S $\triangle$ DBR-SB $\bigcirc$ SFE-S OSFE-SB $\square$ ELC-S $\square$ ELC-SB

Figure 8. Bivariate dispersion plot between mean grain size and standard deviation (a), skewness (b), and kurtosis (c), for the surface (S) and sub-bottom (SB) sediments at Dzilam de Bravo (DBR), San Felipe (SFE), and El Cuyo (ELC), Yucatan. The specific ranges for sediment classification are included.

Figura 8. Gráfica de dispersión bivariada entre el tamaño de grano promedio y la desviación estándar (a), la asimetría (b) y la curtosis (c), para los sedimentos superficiales (S) y del subfondo (SB) en Dzilam de Bravo (DBR), San Felipe (SFE) y El Cuyo (ELC), Yucatán. Se muestran los intervalos específicos para la clasificación de sedimentos.

Conversely, the presence of spaces between dunes without sediment, with or without vegetation, suggests a lack of sediment or that it is in constant motion (Daniell et al. 2008), as occurs at DBR. The seagrass meadows among the dunes at DBR and SFE are subject to a constantly changing dynamics due to the movement of the dunes that temporarily cover them. Once the dune has completely crossed over them they flourish once again. Periods of up to one year have been reported for this to occur (Daniell et al. 2008).

The difference between the true and estimated reference heights suggests that a shallow depth is a determining factor of dune height, because based on their wavelength and sediment type, the dunes could reach greater heights than those observed, as indicated by the theoretical reference heights (Flemming 2000, Xu et al. 2008). los hace hostiles para comunidades vegetales como las fanerógamas marinas. Estos ambientes altamente energéticos no permiten el establecimiento de semillas de las plantas (Ryan et al. 2007, Daniell et al. 2008), lo que explicaría la ausencia de vegetación.

En casos opuestos, se sugiere que la presencia de espacios sin sedimento, con o sin vegetación entre las dunas, indica escasez de sedimento o que está en movimiento constante (Daniell et al. 2008) como es el caso de DBR. Las praderas de pastos marinos entre las dunas de DBR y SFE están sujetas a una dinámica de cambio constante por traslación de las dunas que cubren temporalmente los pastos mientras cruzan sobre ellos. Una vez que la duna los ha cruzado por completo, vuelven a florecer. Se han registrado períodos de hasta un año para esto (Daniell et al. 2008). 
Off Quintana Roo, Tucker and Wright (1990) observed assymetrical, elongated dunes lying transverse to the current. Their wavelengths ranged from 10 to $400 \mathrm{~m}$ and heights from 1 to $3 \mathrm{~m}$, at depths between 5 and $6 \mathrm{~m}$. The troughs between dunes seem to be stabilized by seagrasses (Thalassia testudinum) and macroalgae. These morphological and structural characteristics are similar to those found off the coast of Yucatan and can be explained by the common calcareous origin, as well as by the hydrodynamics caused by the Yucatan Channel, albeit with different magnitudes because of their geographic location (Enríquez et al. 2010). Given the hydrodynamics in this region (Enríquez et al. 2010), it is possible that part of the sediment deposited along the coast of Yucatan comes from sedimentary deposits in the Mexican Caribbean (Cabo Catoche area), with comparable characteristics to those described here.

The direction of dune movement at DBR and SFE is consistent with the direction of longshore sediment transport, (from east to west) off Yucatan (Enríquez et al. 2010). At ELC it is consistent with the theory of the movement of dunes by jumps (Flemming 2000), approaching the coast like a tongue of sand.

\section{Sediment analysis}

The coarser sediment found at ELC and SFE suggests moderate hydrodynamic energy conditions at those sites
En cuanto a la diferencia entre alturas reales y estimadas de referencia, se postula que la baja profundidad es un factor determinante de la altura de las dunas, ya que con base en su longitud de onda y tipo de sedimento, las dunas podrían alcanzar alturas mayores que las observadas, como lo sugieren las alturas teóricas de referencia (Flemming 2000, Xu et al. 2008).

Tucker y Wright (1990) registraron dunas de forma elongada, transversales a las corrientes y asimétricas frente a Quintana Roo. Su longitud de onda varió de 10 a $400 \mathrm{~m}$ y su atlura de 1 a $3 \mathrm{~m}$, a profundidades de entre 5 y $6 \mathrm{~m}$. Se sugiere que los valles entre dunas se estabilizan por pastos marinos (Thalassia testudinum) y macroalgas. Estas características morfológicas y estructurales son similares a las encontradas en la costa de Yucatán y son explicables con base en el origen calcáreo común, así como por la hidrodinámica provocada por el canal de Yucatán, aunque con diferentes magnitudes por su ubicación geográfica (Enríquez et al. 2010). Dada la hidrodinámica en la región (Enríquez et al. 2010), es factible que parte del sedimento depositado en la costa de Yucatán provenga de depósitos sedimentarios en el Caribe mexicano (zona de Cabo Catoche), con características comparables a las aquí descritas.

El sentido del movimiento de las dunas en DBR y SFE es congruente con la dirección del transporte sedimentario (de este a oeste) en la costa de Yucatán (Enríquez et al. 2010). En

Table 2. Descriptive statistics derived from the sedimentological analysis of the samples collected at Dzilam de Bravo, San Felipe, and El Cuyo, Yucatan.

Tabla 2. Estadística descriptiva derivada del análisis sedimentológico de las muestras recolectadas en Dzilam de Bravo, San Felipe y El Cuyo, Yucatán.

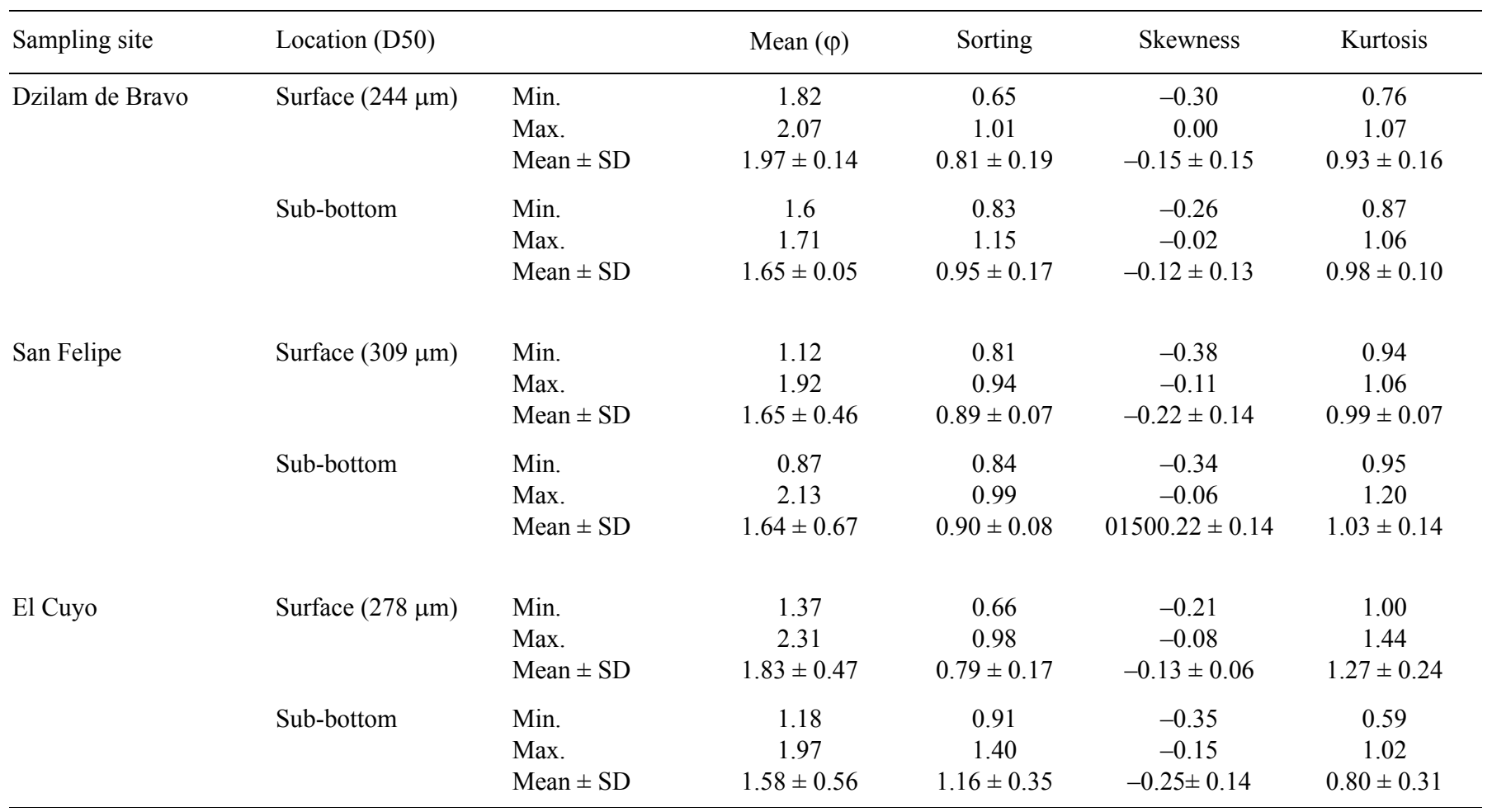


(Nicholas 2003). The finer sediment and less intense energy conditions at DBR may be associated with the east to west circulation and longshore sediment transport patterns (Bartholomä and Flemming 2007).

In this regard, Ruíz (2010) indicated that Yucatan beaches show unstable flake-like particles, susceptible to movement, with low values of the form factor (dimensional grain parameter ranging from 0 to 1 ). In particular, for DBR this author reported the finest sand on the Yucatan coast, with a high form factor $(>0.7)$, which would suggest little chance of movement for the sediments at this site. In contrast, Holbox Island (located close to ELC) had a larger grain size, with a low form factor (less equidimensional particles), which would facilitate the longshore transport of these particles.

Based on this information, the presence of two regimes can be assumed in the study area, the first showing little variation in hydrologic energy, as well as selective transport and deposition, associated with moderately sorted sediments (DBR and SFE), and the second of high turbulence and extreme pulses in intensity and duration that act on the sediment with low selectivity, associated with poorly sorted sediments (ELC) (Martins 2003).

The mesokurtic distribution observed at DBR and SFE is indication of a moderate energy system, where the waves and currents fragment, dissolve, and carry the material. At ELC, however, large energy fluctuations resulted in variable sedimentation, low selectivity at the surface (leptokurtic distribution) and mixing of different grains sizes (platykurtic distribution) in the sub-bottom layer (Santiago and Sambrano 2007).

Finally, the granulometric characteristics recorded for the submarine dunes are consistent with the discriptions of the sand on the beaches of Yucatan (Nolasco-Montero and Carranza-Edwards 1987, Cuevas-Jiménez and Euán-Ávila 2009, Ruíz et al. 2010), suggesting sediment input to coastal areas by these sedimentary deposits.

In summary, the sedimentological and morphological information of the seafloor presented here, together with the available hydrodynamic information, indicate an east to west longshore sediment transport, causing the dunes to move mainly northwestward near the coastline, and an input of sediments from the deposits especially in the easternmost part of the Yucatan peninsula (ELC). This process disperses the sediment along the coastline, causing accumulations in areas with abrupt changes in shoreline orientation (SFE and DBR) and reducing the dimensions of the seafloor shapes towards the center and east of the Yucatan coast, with finer sediments in the areas located farther from the source of sediment to the northeast of the peninsula.

This integral information (sedimentological and morphological) on these marine environments provides the basis for a better understanding of more complex oceanographic processes and for a better management of the ecosystems linked to coastal sedimentary deposits in the region. The ecological
ELC la traslación sería congruente con la teoría del movimiento por saltos de las dunas (Flemming 2000), acercándose a manera de lengua de arena a la línea de costa.

\section{Análisis sedimentológico}

El sedimento más grueso en ELC y SFE sugiere condiciones de energía hidrodinámica moderada en esos sitios (Nicholas 2003). En DBR se presentaron condiciones de menor intensidad de energía y sedimentos más finos, lo que podría asociarse con los patrones de circulación y transporte sedimentario costero de este a oeste (Bartholomä y Flemming 2007).

En este sentido, Ruíz (2010) señala que las playas de Yucatán presentan partículas inestables con tendencia al tipo hojuela, susceptibles al movimiento, y con valores bajos del factor de forma (parámetro dimensional del grano, que varía de 0 a 1). En particular, para DBR, este autor registró la arena más fina de las costas de Yucatán, con un factor de forma alto $(>0.7)$, lo que implicaría poca probabilidad de movimiento para los sedimentos de ésta localidad. En contraste, en la isla de Holbox (ubicada cerca de ELC) se presentó un tamaño de grano mayor y un factor de forma bajo (partículas menos equidimencionales), lo que facilitaría el transporte de estas partículas por la línea de costa.

Con base en esta información, se sugiere la presencia de dos regímenes en las áreas de estudio: uno con poca fluctuación de energía hidrológica, así como transporte y deposición selectivos, asociado a sedimentos con clasificación moderada (DBR y SFE), y otro de alta turbulencia, con variaciones en la energía hidrodinámica, con pulsos extremos en intensidad y duración que actúan sobre el sedimento con poca selectividad, asociado a sedimentos con pobre clasificación (ELC) (Martins 2003).

La distribución mesocúrtica observada en DBR y SFE confirma el indicio de un sistema con energía moderada, donde el oleaje y las corrientes fragmentan, disuelven y arrastran los materiales. Por otro lado, en ELC fuertes oscilaciones de energía provocarían una sedimentación variable, poca selectividad en superficie (distribución leptocúrtica) y mezcla de diferentes tamaños de grano (distribución platicúrtica) en el subfondo (Santiago y Sambrano 2007).

Finalmente, las características granulométricas encontradas en las dunas submarinas son consistentes con descripciones de la arena en las playas de Yucatán (Nolasco-Montero y Carranza-Edwards 1987, Cuevas-Jiménez y Euán-Ávila 2009, Ruíz et al. 2010), sugiriendo aportación de sedimento al margen costero por estos depósitos sedimentarios.

Con la evidencia sedimentológica y morfológica del fondo marino aquí presentada y la información hidrodinámica disponible, se presume un transporte de sedimento dominante en dirección de este a oeste, propiciando una traslación de las dunas primordialmente hacia el noroeste en las cercanías a la línea de costa, y con fuente de sedimentos que provienen de los depósitos con abundante disponibilidad en 
assessment of these sedimentary deposits is crucial to fully understanding the role they play as habitats, barriers against storms and hurricanes, and deposits of sedimentary material for the conservation of Yucatan's sandy shoreline.

\section{ACKNOWLEDGEMENTS}

This study was funded by the CONACYT-Yucatan State Government Joint Fund for the Promotion of Scientific and Technological Research (project 108960). We thank IHS Global, Inc., for providing the software used in this study, and the Coastal Processes and Physical Oceanography Laboratory, especially I Mariño (Centro de Investigación y de Estudios Avanzados, Instituto Politécnico Nacional) for the facilities provided for the sedimentological analysis.

English translation by Christine Harris.

\section{REFERENCES}

Aliotta S, Perillo GME. 1987. A sand wave field in the entrance to Bahía Blanca estuary, Argentina. Mar. Geol. 76: 1-14.

Allen JRL. 1980. Sand waves: A model of origin and internal structure. Sediment. Geol. 26: 281-328.

Álvarez-Góngora C, Herrera-Silveira JA. 2006. Variations of phytoplankton community structure related to water quality trends in a tropical karstic coastal zone. Mar. Pollut. Bull. 52: 48-60. http://dx.doi.org/10.1016/j.marpolbul.2005.08.06.

Ashley GM. 1990. Classification of large-scale subaqueous bedforms: A new look at an old problem. J. Sediment. Petrol. 60: 160-172.

Bartholdy J, Flemming BW, Bartholoma A, Ernstsen VB. 2005. Flow and grain size control of depth-independent simple subaqueous dunes. J. Geophys. Res. 110, F04S16. http://dx.doi.org/10.1029/2004JF000183.

Bartholomä A, Flemming BW. 2007. Progressive grain-size sorting along an intertidal energy gradient. Sediment. Geol. 202: 464-472. http://dx.doi.org/10.1016/j.sedgeo.2007.03.010.

Capurro L. 2000. Un gran ecosistema costero: La península de Yucatán. Avance y Perspectiva 22:69-75.

Capurro L, Euán J, Herrera J. 2002. Manejo sustentable del ecosistema costero de Yucatán. Avance y Perspectiva 21: 195-204.

Cuevas-Jiménez A, Euán-Ávila J. 2009. Morphodynamics of carbonate beaches in the Yucatan Peninsula. Cienc. Mar. 35: 307-320.

Daniell JJ, Harris PT, Hughes MG, Hemer M, Heap A. 2008. The potential impact of bedform migration on seagrass communities in Torres Strait, northern Australia. Cont. Shelf Res. 28: 2188-2202. http://dx.doi.org/10.1016/j.csr.2008.03.036.

Enríquez C, Mariño-Tapia IJ, Herrera-Silveira JA. 2010. Dispersion in the Yucatan coastal zone: Implications for red tide events. Cont. Shelf Res. 30: 127-137. http://dx.doi.org/10.1016/j.csr.2009.10.005.

Flemming BW. 2000. The role of grain size, water depth and flow velocity as scaling factors controlling the size of subaqueous dunes. In: Trentesaux A, Garlan T (eds.), Marine Sandwave Dynamics. Proceedings of International Workshop, 23-24 March 2000, University of Lille, France, pp. 55-60. el extremo este de la península de Yucatán (ELC). Este proceso dispersa el sedimento a lo largo de la línea de costa, provocando acumulaciones en zonas con cambios abruptos de orientación de la costa (SFE y DBR) y disminuyendo las dimensiones de las formas de fondo hacia el centro y poniente de la costa yucateca, con sedimentos más finos en las zonas alejadas de la fuente de sedimento al noreste de la península.

La información integral (sedimentológica y morfológica) proporcionada acerca de estos ambientes marinos permite establecer líneas base para el entendimiento de procesos oceanográficos más complejos, permitiendo un manejo adecuado de los ecosistemas ligados a los depósitos sedimentarios costeros en la región. La valoración ecológica de estos depósitos sedimentarios es crucial para el completo entendimiento de la función que éstos desempeñan como hábitat, barrera contra tormentas y huracanes, así como depósitos de material sedimentario para la conservación del litoral arenoso en Yucatán.

\section{Agradecimientos}

Los autores expresan su agradecimiento al Fondo Mixto CONACYT-Gobierno del Estado de Yucatán por el financiamiento (proyecto \#108960). También agradecemos a la empresa IHS Global, Inc. por su aportación con el software utilizado en este estudio, y al Laboratorio de Oceanografía Física y Procesos Costeros, en espacial a I. Mariño (Centro de Investigación y de Estudios Avanzados, Instituto Politécnico Nacional) por las facilidades brindadas para los análisis sedimentológicos.

Folk RL. 1980. Petrology of Sedimentary Rocks. Hemphill, Austin, Texas, $182 \mathrm{pp}$.

Gómez EA, Cuadrado DG, Pierini JO. 2010. Sand transport on an estuarine submarine dune field. Geomorphology 121: 257-265.

Le Bot S, Idier D, Garlan T, Trentesaux A, Astruc D. 2000. Dune dynamics: From field measurements to numerical modelling. Application to bathymetric survey frequency in the CalaisDover Strait. In: Trentesaux A, Garlan T (eds.), Marine Sandwave Dynamics. Proceedings of International Workshop, 23-24 March 2000, University of Lille, France, pp. 101-108.

Lugo-Hupb J, Aceves-Quesada JF, Espinosa-Pereña R. 1992. Rasgos geomorfológicos mayores de la península de Yucatán. Univ. Nal. Autón. Méx. Rev. Inst. Geol. 10: 143-152.

Martins LR. 2003. Recent sediments and grain-size analysis. Gravel (Porto Alegre, Brazil), CD, 1: 90-105.

Murdoch A, Azcue JM. 1995. Manual of Aquatic Sediment Sampling. Lewis Publishers, Boca Raton, 219 pp.

Nicholas JRJ. 2003. Grain size analysis of the sediments of Spurn Head, East Yorkshire, England. PhD thesis, Division of Research and Advanced Studies of the University of Cincinnati, 123 pp.

Nolasco-Montero E, Carranza-Edwards A. 1987. Estudio sedimentológico regional de playas de Yucatán y Quintana Roo, México. An. Inst. Cienc. Mar Limnol. Univ. Nal. Autón. Méx. 15: 49-66. 
Palomino D, Vázquez JT, Díaz del Río V, Fernández-Salas LM. 2009. Estudio de los procesos sedimentarios recientes de la Bahía de la Palma a partir del análisis de la morfología y la respuesta acústica (Islas Baleares, Mediterráneo occidental). Rev. Soc. Geol. Esp. 22: 79-93.

Perillo GME. 2001. Hacia una nomenclatura y clasificación de formas de fondo transversales generadas por flujos de agua. Rev. Asoc. Arg. Sedimentol. 8: 37-56.

Peterson CD, Stock E, Hart R, Percy D, Hostetler SW, Knott JR. 2010. Holocene coastal dune fields used as indicators of net littoral transport: West Coast, USA. Geomorphology 116: $115-134$. http://dx.doi.org/10.1016/j.geomorph.2009.10.013.

Ruíz CD, Ruíz MG, Mendoza BE y Silva CR. 2010. Distribución del sedimento en las costas de Yucatán y Quintana Roo. XXI Congreso Nacional de Hidráulica, Guadalajara, Jalisco, México, October 2010.

Ryan DA, Brooke BP, Collins LB, Kendrick GA, Baxter KJ, Bickers AN, Siwabessy PJW, Pattiaratchi CB. 2007. The influence of geomorphology and sedimentary processes on shallow-water benthic habitat distribution: Esperance Bay, Western Australia. Estuar. Coast Shelf Sci. 72: 379-386;

http://dx.doi.org/10.1016/j.ecss.2006.10.008.

Santiago C, Sambrano J. 2007. Estudio sedimentológico de las geoformas litorales acumulativas recientes en el archipiélago de Los Testigos, Dependencias Federales. Sapiens 8: 71-82.

Sahu BK. 1964. Depositional mechanisms from the size analysis of clastic sediments. J. Sediment. Petrol. 40: 73-83.

Todd BJ. 2005. Morphology and composition of submarine barchan dunes on the Scotian Shelf, Canadian Atlantic margin. Geomorphology 67: 487-500; http://dx.doi.org/10.1016/j.geomorph.2004.11.016.

Tucker ME, Wright VP. 1990. Carbonate sedimentology. Blackwell Science, Oxford, $481 \mathrm{pp}$.

Xu JP, Wong FL, Kvitek R, Smith DP, Paull CK. 2008. Sandwave migration in Monterey submarine canyon, central California. Mar. Geol. 248: 193-212;

http://dx.doi.org/10.1016/j.margeo.2007.11.005.

Received May 2012, received in revised form October 2012, accepted November 2012. 